in each culture flask. The external medium at this time contained only $\mathrm{l} \cdot \mathrm{l} \mathrm{mgm}$. of nitrogen (Kjeldahl. Gunning) of which $0.6 \mathrm{mgm}$. was nitrate nitrogen. Thus $8.5 \mathrm{mgm}$. of nitrogen were lost, presumably in elementary form.

Similar losses of nitrogen have been observed when daffodil leaves were floated aseptically on glucose media ( 3 per cent, buffered by phosphate mixtures to $p \mathrm{H} \mathrm{5.4)} \mathrm{containing} \mathrm{an} \mathrm{inorganic} \mathrm{source} \mathrm{of} \mathrm{nitrogen}$ such as ammonium or potassium nitrate. Of the nitrogen absorbed from the medium, about half is normally lost, the remainder being retained in the leaves. In contrast, if organic sources of nitrogen (such as asparagine, alanine or urea) are used, the whole of the nitrogen absorbed can be recovered in the leaves. It may be noted that considerable losses of nitrogen are always associated with low aminonitrogen content of the leaf tissues.

W. H. Pearsall.

M. C. Billimoria.

Botanical Department, University, Leeds. Oct. 20 .

I Biochem. J., 29, 1389 (1935).

Van Slyke, $J$. Biol. Chem., 12, 375 (1912).

${ }^{3}$ Biochem. J., 3, 87 (1907).

\section{Route of Migrating Parasites in Ruminants}

Mr. W. M. Webster, veterinarian of this College, has shown me an adult specimen of the lungworm Dictyocaulus filaria that he found in an undamaged condition in the small intestine of a hogget.

This observation, it appears to me, reveals something of the movements of parasites that undergo the lung journey in ruminants.

In the first place, the specimen must have been coughed from the lungs and then swallowed. It does not seem possible that it could have been involved in the process of rumination for, on account of its relatively large size, it would have been crushed The conclusion therefore follows that the worm during its journey to the small intestine could not have spent a period in the rumen.

Perhaps the eggs or larvæ of the various lungworms and other worms, in their passage from the lungs, behave in a similar manner, and proceed directly from the gullet to the reticulum.

Zoology Department,

J. H. Tethey.

Massey Agricultural College,

Palmerston North,

New Zealand.

Aug. 2.

\section{Resonance Structures of Carbon Dioxide, Carbonyl} Sulphide and Carbon Disulphide

By comparing experimental heats of formation with bond energies derived from compounds without alternative Lewis structures, Pauling and Sherman ${ }^{1}$ deduce resonant structures for carbon dioxide, carbonyl sulphide, and carbon disulphide, of the type :

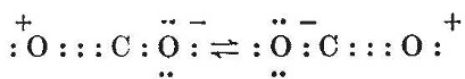

but the impossibility of obtaining a valuation of the bond energies of partially ionic bonds from thermal data does not permit of a more penetrating analysis of the resonance of these compounds along these lines.

Gray and Cruickshank ${ }^{2}$ have demonstrated the presence of resonance in certain compounds by considering diamagnetic susceptibilities. As partially ionic bonds can be evaluated magnetically, a greatly increased number of theoretically possible structures can be considered.

The diamagnetic susceptibilities of the above compounds are :

$$
\mathrm{CO}_{2}-20 \cdot 80^{3} ; \mathrm{COS}-32 \cdot 36 ; \mathrm{CS}_{2}-42 \cdot 29 \text {, }
$$

and these experimental susceptibilities can be com. pared with the theoretically possible states of the

\begin{tabular}{|c|c|c|c|c|c|}
\hline & \multirow[b]{2}{*}{$E$} & \multirow[b]{2}{*}{ Reson. $E$} & \multicolumn{2}{|c|}{ Susceptibility of } & \multirow{2}{*}{$\begin{array}{l}\text { Expt. } \\
\text { suscept. }\end{array}$} \\
\hline & & & $x=\mathrm{C}=\mathrm{x}$ & $: \ddot{x}: \mathrm{c}::: x^{+}$ & \\
\hline $\begin{array}{l}\mathrm{CO}_{2} \\
\mathrm{COS}\end{array}$ & $\begin{array}{l}16 \cdot 79 \\
14 \cdot 55\end{array}$ & $\begin{array}{l}1.37 \mathrm{ve} . \\
0.84, "\end{array}$ & $\begin{array}{c}-2 \cdot 73 \\
-12 \cdot 31 \\
\end{array}$ & $\begin{array}{l}-20 \cdot 80 \\
-38 \cdot 00\end{array}$ & $\begin{array}{l}-20 \cdot 80 \\
-32 \cdot 36\end{array}$ \\
\hline $\mathrm{CS}_{2}$ & $12 \cdot 46$ & $0.46 "$ & $-22 \cdot 54$ & $\begin{array}{l}-42 \cdot 79 \mathrm{~J} \\
-59 \cdot 84\end{array}$ & $-42 \cdot 29$ \\
\hline
\end{tabular}
molecules and with Pauling's resonance energies.

Neither of the calculated values for the structures $\mathrm{O}=\mathrm{C}=\mathrm{O}, \mathrm{O}=\mathrm{C}=\mathrm{S}, \mathrm{S}=\mathrm{C}=\mathrm{S}$, agrees with the $e \mathrm{x}$. perimental value, this being what one would expect from the suggestions of Pauling and Sherman, but in the case of carbon dioxide a resonance

$$
\text { : } \mathrm{O}::: \mathrm{C}: \ddot{\mathrm{O}^{-}}: \rightleftharpoons: \ddot{\mathrm{O}}: \mathrm{C}::: \mathrm{O}^{+}
$$

would give for the susceptibility $-20 \cdot 80$, which is exactly what is found experimentally $(-20 \cdot 80)$, a convincing demonstration of resonance in the carbon dioxide molecule.

The introduction of one sulphur atom is accompanied by a fall in resonance energy. In carbonyl sulphide two ionic states are possible. Direct re. sonance between these states gives too high a calcu. lated susceptibility, but the existence of an inter. mediate state $\mathrm{O}=\mathrm{C}=\mathrm{S}$ enables the experimental value to be accounted for.

$$
: \mathrm{S}^{+}:: \mathrm{C}: \underset{. \cdot}{\ddot{\mathrm{O}}}: \rightleftharpoons \mathrm{S}=\mathrm{C}=\mathrm{O} \rightleftharpoons: \ddot{\mathrm{S}}: \ddot{\mathrm{C}}::: \mathrm{O}:{ }^{+}
$$

If equal times were spent in these three states, the calculated susceptibility would be $-31 \cdot 02$, compared with the experimental value $-32 \cdot 36$.

A further fall in resonance energy takes place on passing to carbon disulphide, and in agreement with this, resonance between

$$
: \ddot{\mathrm{S}}: \mathrm{C}:: \stackrel{+}{ }: \stackrel{\mathrm{S}}{*} \rightleftharpoons \mathrm{S}=\mathrm{C}=\mathrm{S}
$$

is suggested by the diamagnetic susceptibility of carbon disulphide (calculated $-41 \cdot 19$; experimental $-42 \cdot 29$ ).

The resonance in amides suggested by Pauling is also confirmed magnetically :<smiles>[R]C(N)=O</smiles> 